\title{
The Structural Analyses and Tectonic Interpretations of Shaikhan Anticline- Northern Iraq
}

\author{
Nabeel K. Al-Azzawi Saddam E. M. Al-Khatony \\ Department of Geology \\ College of Science \\ Mosul University
}

(Received 28/5/2009, Accepted 29/10/2009)

\begin{abstract}
Structural analyses including fold geometry, Harmonic (Fourier) analysis, vertical investigation of fold style, thickness change test and joints analysis were carried on Shaikhan Anticline which is one of the Foreland Folds of Iraq. Geometrical analysis of five traverses revealed its asymmetry except the area of the second traverse which shows symmetrical form. It is verging towards the north except the area of the first one. The anticline axis changes its direction along the anticline. It trends east-southeast in the eastern part, swings towards the eastnortheast and returns to the first direction in the west. These swings were caused by two sinistral strike-slip faults displacing oblige to the fold axis.

Fourier analysis revealed that the fold has low developed shape at the plunges. It is of chevronic-sinusoidal shape. While it has high developed shape (Parabolic-semi Elliptical) at the central part, along the third traverse which influenced by the transpression of the strike-slip fault.

The vertical investigation of fold style showed that the fold axis direction was constantly anticlockwise changing from the Late Eocene to Middle Miocene and rotated clockwise from the Middle to Late Miocene. This axis also has a specific direction difference, in the folded strata between the Gercus And the Pila Spi formations. This was considered as an indicator for the listric fault reactivation. The suture listric fault was forced the anticline to the northward vergence. Formation thickness changes confirm the presence of this fault revealing that the formations younger than the Gercus are thicker in the southern limb. This indicates that the suture listric fault is of normal type.
\end{abstract}




\section{التحليلات التركيبية والتفسيرات التكتونية لطية الشيخان

$$
\text { المحدبة- شمالي العراق }
$$

$$
\text { نبيل قادر العزاوي }
$$

\section{الملخص}

شملت التحليلات التركيية لطية الثيخان المحدبة هندسية الطية، التحليل الهارموني، الاستقصاء العمودي، تغاير السماكات وتحليل الفواصل والتي هي احد طيات نطاق الفورلاند في العراق. وأظهر التحليل

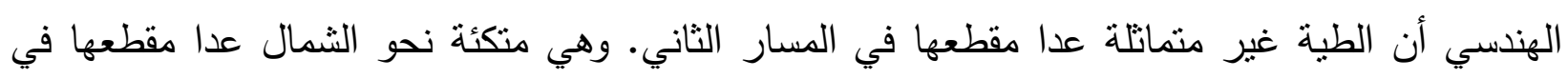

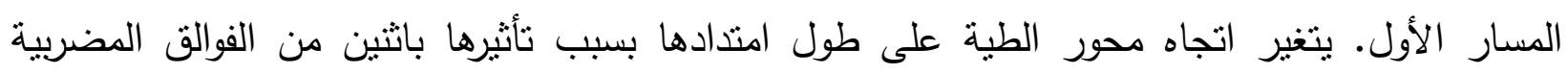
اليسارية. فهو شرق-جنوب شرق في الجزء الثرقي ويتغير فيصبح شرق -شمال شرق ثم يعود إلى الاتجاه الأول في جزء الطية الغربي. تبين من تحليل فورير أن نطور الطية واطئ عند غاطسيها (شيفرونية-جيبية)، بينما يكون تطورها

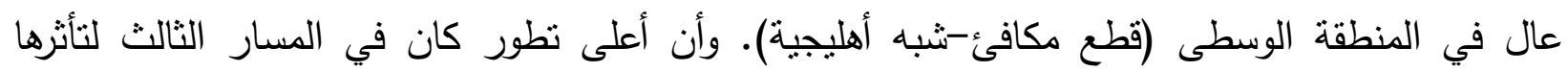
بالفوالق المضربية. أما الاستقصاء العمودي لطراز الطية فقد أظهر أن محور الطية قد تغير باتجاه عكس عقرب الساعة

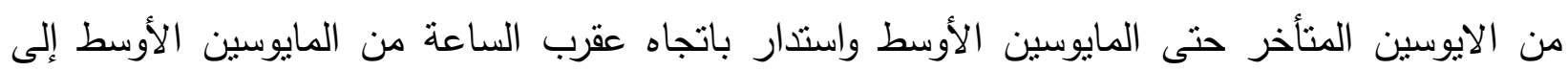
المايوسين الأعلى. وإن هذا الدحور يتغير بشكل ملحوظ بين الطبقات المطوية لتكوين الجركس والبلاسبي.

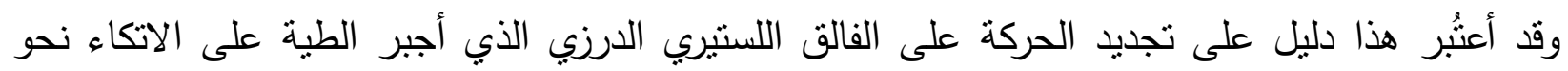

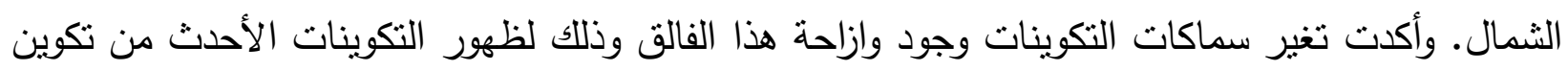
الجركس أسمك في الجناح الجنوبي. وهذا أيضاً دليل على أن الفالق اللستيري الدرزي هو هو من النوات 